\begin{tabular}{|l|l|l||}
\hline \multicolumn{2}{|c|}{ PublisherInfo } \\
\hline \hline PublisherName & $:$ & BioMed Central \\
\hline \hline PublisherLocation & $:$ & London \\
\hline \hline PublisherImprintName & $:$ & BioMed Central \\
\hline \hline
\end{tabular}

\title{
Shedding light on gene regulation
}

\begin{tabular}{|l|c|l||}
\hline \multicolumn{2}{|c|}{ ArticleInfo } \\
\hline \hline ArticleID & $:$ & 4573 \\
\hline \hline ArticleDOI & $:$ & $10.1186 /$ gb-spotlight-20020906-02 \\
\hline \hline ArticleCitationID & $:$ & spotlight-20020906-02 \\
\hline \hline ArticleSequenceNumber & $:$ & 239 \\
\hline \hline ArticleCategory & $:$ & Research news \\
\hline ArticleFirstPage & $:$ & 1 \\
\hline \hline ArticleLastPage & $:$ & 2 \\
\hline \hline & & RegistrationDate : 2002-9-6 \\
\hline ArticleHistory & $:$ & OnlineDate \\
\hline \hline ArticleCopyright & $:$ & BioMed Central Ltd2002-9-6 \\
\hline \hline ArticleGrants & $:$ & \\
\hline \hline ArticleContext & $:$ & 130593311 \\
\hline \hline
\end{tabular}




\section{Jonathan B Weitzman}

Email: jonathanweitzman@hotmail.com

Experimental systems in which gene expression can be carefully regulated are powerful tools for investigating gene function. In an Advanced Online Publication in Nature Biotechnology, Shimizu-Sato and colleagues describe an ingenious gene expression system that exploits a light-sensitive protein from plants.

The system is binary, like the classical yeast two-hybrid system, and is based on a light-induced interaction between two fusion proteins. One is a fusion between the plant PhyB phytochrome and the DNA-binding domain of the yeast transcriptional activator Gal4, while the other contains the plant Pif3 basic helix-loop-helix protein fused to the Gal4 activation domain. A controlled transgene can be 'turned on' by red light, and 'turned off' again by far-red light. The findings demonstrate that their system works well in yeast, and they predict that it could be used in any light-accessible eukaryotic cell to offer a noninvasive, inexpensive and non-toxic gene induction system.

\section{References}

1. Conditional control of gene expression in the mouse.

2. Nature Biotechnology, [http://www.nature.com/nbt/] 